\title{
Recent Trends and Future Directions on Value Addition of Irish Potato (Solanum Tuberosum L.) among Smallholder Farmers
}

\author{
Jacinta Mlaviwa ${ }^{a}$, Edward Missanjo ${ }^{\text {b* }}$ \\ ${ }^{a}$ Department of Agriculture, Malawi Advertist University, Lake View Campus, P.O. Box 148, Ntcheu, Malawi \\ ${ }^{b}$ Department of Forestry, Forestry Research Institute of Malawi, P.O. Box 270, Zomba, Malawi
}

\begin{abstract}
Irish potato (Solanum tuberosum L.) value addition has the potential to enhance food security, household income and nutrition. This cross-sectional study was, therefore, conducted to examine value addition of Irish potato among smallholder farmers in Ntcheu, central Malawi. Data was collected using a standard structured questionnaire administered through face-to-face interviews. The results revealed that there were significant differences $\left(X^{2}=103.3 ; p<0.001\right)$ on value addition techniques practiced by farmers. The following value addition techniques were identified: chips $(65 \%)$, packaging $(27.5 \%)$, crisps $(25 \%)$, grading $(12.5 \%)$, salad $(5 \%)$, baking $(5 \%)$, soup $(2.5 \%)$ and grounding into flour $(2.5 \%)$. It was noted that factors influencing Irish potato value addition among farmers significantly $\left(X^{2}=8.020 ; p=0.046\right)$ differed. The majority $(70 \%)$ of the farmers were influenced by knowledge of value addition, followed by ready markets for products $(57.5 \%)$, while a few were influenced by capital $(45.5 \%)$ and availability of value addition equipment $(40.0 \%)$. The study further revealed that education level and group participation significantly $(P<0.05)$ influenced Irish potato value addition technique practices. Farmers with secondary education level or above and those in Irish potato group production are involved in diverse value addition techniques. Encouraging farmer group formation, access to loans to buy value addition equipment, linking farmers with supermarkets, and farmer's exposure to field days and workshops are the strategies identified to promote effective Irish potato value addition among smallholder farmers.
\end{abstract}

\section{Keywords:}

Irish Potato;

Value Addition;

Group Formation;

Markets;

Field days.

\section{Article History: \\ Received: 13 November 2018 \\ Accepted: 11 January 2019}

\section{1- Introduction}

Irish potato (Solanum tuberosum L.) is grown worldwide and in most developing countries it is considered the most important food crop after maize, rice and wheat in terms of volume of production. Irish potato is the fourth most important food crop in the world, with annual production approaching 300 million tons. More than one third of the global Irish potato output comes from developing countries [1]. Malawi is Sub-Saharan Africa's biggest Irish potato producer (Table 1) [2]. In Malawi, it is an important food crop as well as a cash crop. So Irish potato farming in Malawi is helping smallholder farmers feed their families and boost their incomes by supplying to local markets [3].

Irish potato can play a very important role in food security strategy for Malawi since it is the most efficient tuber crop in Malawi in terms of tuber yield and days to maturity. It matures in about $80-90$ days as compared to 12 months for cassava. Therefore, because of the short maturity period, the crop is produced almost throughout the year making it the highest yielding tuber crop in Malawi [3].

Irish potato production in Malawi is mainly concentrated in Dedza, Ntcheu and Rumphi districts. There has been a steady increase of farmers growing Irish potato in Malawi from 12,000 farmers in 2012 to 55,000 farmers in 2015. It is consumed as a substitute for bread at breakfast in most households either boiled and a few instances as chips. Average per capita consumption of Irish potato in Malawi is about $118 \mathrm{~kg}$ per year [4]. Nutritionally, Irish potato is a good source

* CONTACT: Edward.em2@gmail.com

DOI: http://dx.doi.org/10.28991/esj-2019-01167

(C) This is an open access article under the CC-BY license (https://creativecommons.org/licenses/by/4.0/). 
of vitamins $\mathrm{C}$ and B6, manganese, phosphorus, niacin and pantothenic acid [5, 6].

Non-food uses of Irish potato include: glue, animal feed and fuel-graded ethanol [7]. Irish potato starch is also widely used by the pharmaceutical, textile, wood and paper industries as an adhesive, binder, texture agent and filler, and by oil drilling firms to wash boreholes. Irish potato starch is a $100 \%$ bio-degradable substitute for polystyrene and other plastics. It is used, for example, in disposable plates, dishes and knives, while the peel and other "zero value" wastes from potato processing are rich in starch that can be liquefied and fermented to produce fuel-grade ethanol.

Table 1. Irish potato production yield for some Sub-Saharan African Countries

\begin{tabular}{ccccc}
\hline No. & Country & Harvested Area (ha) & Yields (t/ha) & Qty Produced (tones) \\
\hline 1 & Malawi & 185,000 & 11.9 & $2,200,000$ \\
2 & South Africa & 58,000 & 34.0 & $1,972,391$ \\
3 & Rwanda & 133,000 & 9.0 & $1,200,000$ \\
4 & Nigeria & 270,000 & 3.1 & 843,000 \\
5 & Kenya & 120,000 & 6.7 & 800,000 \\
6 & Uganda & 90,000 & 7.0 & 650,000 \\
7 & Angola & 120,000 & 5.1 & 615,000 \\
8 & Ethiopia & 73,095 & 7.2 & 525,657 \\
\hline
\end{tabular}

Source: World Bank Report [8]

Irish potato production has also been influenced by other factors, ranging from lifestyle changes, historical and cultural factors and evolution of testers of preferences for tubers. The rate of population growth and urbanization has increased Irish potato consumption especially in the form of chips potato salad, dry chips, crisps and studies show that the demand is likely to increase [9]. Present average yield of 7500 to $10000 \mathrm{~kg}$ per hectare, fresh weight can be increased to between $15000 \mathrm{~kg}$ to $20000 \mathrm{~kg}$ per hectare. The objective of Malawi government therefore is to improve yield in order to improve farmer's income and food security.

Initially, utilization of Irish potato in Malawi was limited to boiling and chips but currently, this has been changing to value addition. Value addition is the process of changing or transforming a product from its original state to a more valuable state [10]. Value addition of Irish potato involves processing it into product such as chips, salad, dry chips and crisps, desired by customers, grading into different kinds, sizes and quality, packaging the potatoes into attractive plastic papers, plastic containers, wooden boxes, and synthetic fiber sacks.

Adding values to Irish potato has the potential to enhance the production of the crop and further can play important place in the food or nutritional security and income generation in rural households and even urban markets [10, 11]. The need to add value to Irish potato as it is perceived by farmers could maximize on their revenue. Research carried out by International Potato Centre (CIP) on Irish potato production in developing countries found that values addition is an important post-harvest need [12]. Despite these documented initiative and interests in the need for value addition, that value addition increases revenue, preliminary investigations shows that majority of smallholder Irish potato farmers in Malawi had not embraced value addition [13]. The present study, therefore, examined value addition of Irish potato among smallholder farmers in Ntcheu, central Malawi. Specific objectives of the study were: (1) to find out value addition techniques being practiced by smallholder farmers in Njolomole EPA, (2) to identify factors that influence Irish potato value addition among smallholder farmers in Njolomole EPA, and (3) to identify possible strategies on how to promote effective Irish potato value addition among smallholder farmers in Ntcheu, central Malawi.

\section{2- Methods and Materials}

\section{2-1-Study Area}

The study was conducted in Njolomole Extension Planning Area (EPA), Ntcheu district, central Malawi. Njolomole EPA was chosen as a study area because it is one of the areas that leads with Irish potato growers and those involved in value addition. It has a total population of about 15300 smallholder farmers and 7000 Irish potato growers. It is located $14^{0} 38^{\prime} \mathrm{S}, 34^{0} 33^{\prime} \mathrm{E}$ and about $1440 \mathrm{~m}$ above the sea level (Figure 1). It receives $1800 \mathrm{~mm}$ to $1900 \mathrm{~mm}$ rainfall per annum, with an annual temperature of about $18^{\circ} \mathrm{C}$. Njolomole EPA has a well-drained loam soil suitable for Irish potato growing and it is situated about $140 \mathrm{~km}$ southeast of Lilongwe the capital. 


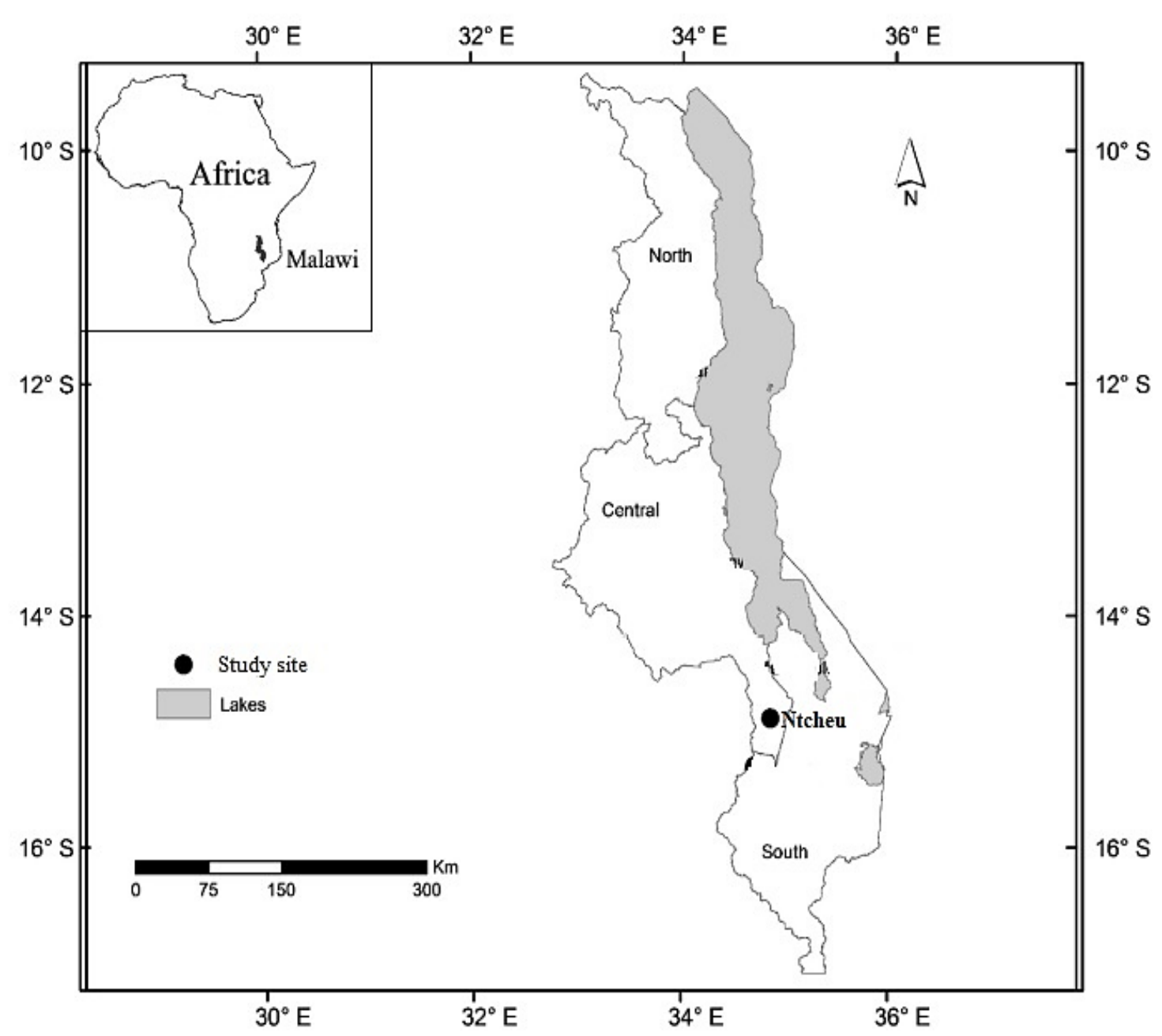

Figure 1. Map of Malawi showing the location of the study Area

\section{2-2-Study Design and Sample Size}

A study design is a master plan specifying methods and procedures for collecting and analysing the required data. It is a means that is to be followed in completing a study. The study design helps the researcher to obtain relevant data to fulfil the objectives of the study [14]. There are three types of study design namely; descriptive, exploratory and causal study designs. This study used a descriptive study design. This is because descriptive studies are concerned with specific predictions, narrations of facts and characteristics concerning individuals, groups or situations.

Sample size was determined using the Equation 1 [15]:

$$
n=\frac{N * X}{X+N-1}
$$

Where: $\mathrm{n}$ is the sample size, $\mathrm{N}$ is the population size, $\mathrm{X}$ is a defined as:

$$
X=z^{2} p q / e^{2}
$$

Where $p$ is proportion of the population containing the major attribute of interest, $q$ is $(1-p), z$ is the standard variate at a given confidence level $(\alpha=0.05)$, and e is the acceptable error (precision). A recommended allowable error ranges from $1 \%$ to $10 \%$ [15]. In this study, a $5 \%$ error rate, a standard proportion $(p)$ of 0.5 , and z-score at $95 \%$ confidence level $(\alpha=0.05)$ of 1.96 was used. Therefore, the expected minimum sample size was 365 farmers. However, 382 Irish potato smallholder farmers were used as a sample size in this study.

\section{2-3-Data Collection and Analysis}

The data for the study was collected in May and June 2017 through a structured questionnaire, with multiple-choice, open ended and Likert scale questions administered through face-to-face interviews. Purpose sampling was derived to 
select Irish potato smallholder farmers in Njolomole EPA, Ntcheu. Purpose sampling is a non-probability sample that is selected based on the characteristics of the population and objective of the study $[15,16]$. In this case, it was based on the smallholder farmers who grow Irish potato in Njolomole EPA, Ntcheu. The questionnaire was pre-tested on a few selected smallholder Irish potato farmers in Njolomole EPA, Ntcheu. The easiness of completion of the questionnaire and ambiguity of questions were noted and subsequently revised before a large-scale interview was conducted. Farmers were asked on socio-demographic characteristics, Irish potato value addition techniques practiced, factors that influenced them to practice Irish potato value addition, challenges faced in Irish potato value addition, and strategies to promote effective value addition of Irish potato

Data collected was analysed using SPSS 24 for Windows and Microsoft Excel to generate descriptive statistics (frequencies/proportions). The Chi-square $\left(\mathrm{X}^{2}\right)$ test was used to assess the influence of farmers socio characteristics on Irish potato value addition. The values of $P<0.05$ was considered as significant. The $\mathrm{X}^{2}$ test was used because of its ability to analyse enumerative data. Data on challenges was analysed using Likert scale. Likert scale analysis was used because of its ability to measure levels of agreement/disagreement.

\section{3- Results}

\section{3-1- Socio-demographic Characteristics of Respondents}

The majority (67.5\%) of the respondents were male, and most (57.5\%) of the respondents fell within the age bracket of 20 - 29 years. This indicates that most of value addition techniques of Irish potato are conducted by male and the youth. Majority (55.0\%) of the respondents were single (not married). Most $(90.0 \%)$ of the respondents had undergone formal education, with the majority $(60.0 \%)$ having attained primary education, followed by those attained secondary school level of education $(25 \%)$ and few $(5.0 \%)$ had tertiary education. Majority $(85.0 \%)$ of the respondents depends on food crop farming as a main source of income. All the smallholder's farmers $(100 \%)$ practice at least one value addition technique of Irish potato. However, most of the respondents $(77.5 \%)$ were not members of any Irish potato production group (Table 2). The reasons for those who joined Irish potato production groups significantly $\left(X^{2}=17.361 ; p=0.002\right)$ differed. Majority (100\%) of the smallholder's farmers joined Irish potato production group for purchase of inputs, followed by group marketing $(77.8 \%)$, then farmer training $(55.6 \%)$, while a few (44.4\%) joined the Irish potato production groups for group lending (Figure 2).

\section{3-2- Irish Potato Value Addition Techniques}

Summary of the results on Irish potato value addition techniques practiced by smallholder famers are presented in Figure 3. The results show that there were significant differences $\left(X^{2}=103.3 ; p<0.001\right)$ on value addition techniques practiced by smallholder farmers. The following value addition techniques were identified chips (65\%), packaging $(27.5 \%)$, crisps (25\%), grading (12.5\%), salad (5\%), baking (5\%), soup (2.5\%) and grounding into flour (2.5\%).

Figure 4 shows that there were significant differences $\left(X^{2}=42.657 ; p<0.001\right)$ on Irish potato value addition techniques practiced between those farmers in groups and those who did not join any Irish potato production group. Majority of smallholder farmers who joined groups are involved in diverse value addition techniques (crisps-15.5\%, grading-13.8\%, packaging- $12.1 \%$, baking-5.2\%, salad-3.4\%, soup-3.2\% and flour-1.7\%) compared to few (chips$65.0 \%$, grading- $13.8 \%$, packaging-6.7\%, baking-1.7\% and crisps-1.7\%) for those who did not join any group.

Motivation factors among Irish potato smallholder farmers for engaging in value addition techniques significantly $\left(X^{2}=33.831 ; p<0.001\right)$ differed (Figure 5$)$. The majority $(78 \%)$ of the Irish potato smallholder farmers engaged in value addition technique in order to generate high income, followed by to improve shelf life of the products direct (12\%), then to penetrate into high value market (7\%), and few (3\%) because of buyer's demand.

Table 2. Socio-demographic characteristics

\begin{tabular}{lcc}
\hline Variable & Frequency & Percentage \\
\hline Age group (years) & 153 & \\
$\leq 19$ & 220 & 40.0 \\
$20-29$ & 9 & 57.5 \\
$\geq 30$ & & 2.5 \\
\hline Gender & 124 & \\
\hline Female & 258 & 32.5 \\
Male & & 67.5 \\
\hline Marital Status & \\
\hline
\end{tabular}




\begin{tabular}{lcc}
\hline Single & 210 & 55.0 \\
Married & 143 & 37.5 \\
Divorced & 29 & 7.5 \\
\hline Education Level & & \\
\hline None & 38 & 10.0 \\
Primary & 229 & 60.0 \\
Secondary & 96 & 25.0 \\
Tertiary & 19 & 5.0 \\
\hline Main Source of Income & & \\
\hline Food crop farming & 325 & 85.0 \\
Cash crop farming & 29 & 7.5 \\
Livestock keeping & 9 & 2.5 \\
Piece work & 19 & 5.0 \\
\hline Group membership & & \\
\hline Yes & 86 & 22.5 \\
No & 296 & 77.5 \\
\hline Involvement in value addition technique & \\
\hline Yes & 382 & 0.0 \\
No & 0 &
\end{tabular}

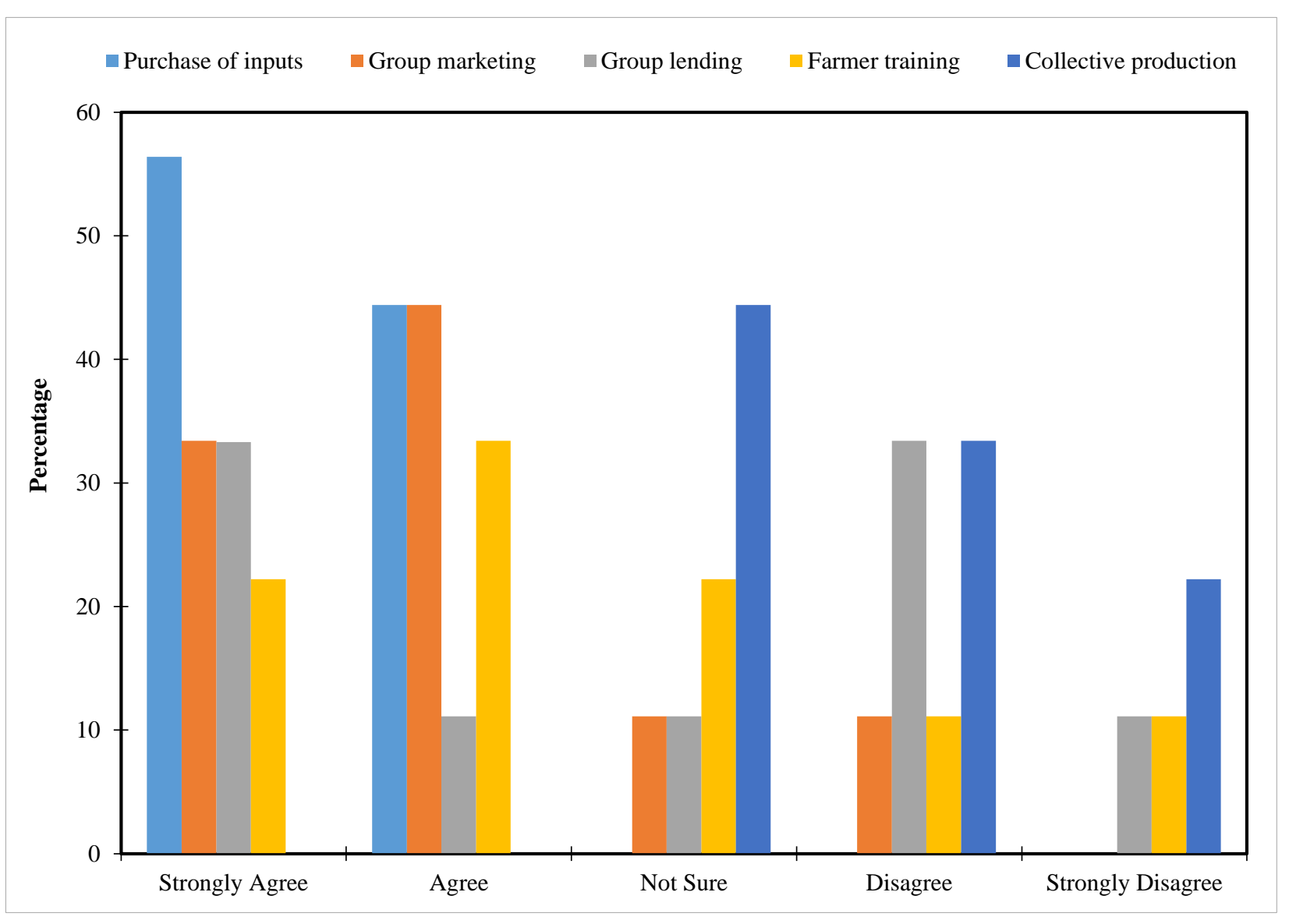

Figure 2. Reasons for joining Irish potato production group

$X^{2}=17.361 ; d f=4 p=0.002$ 


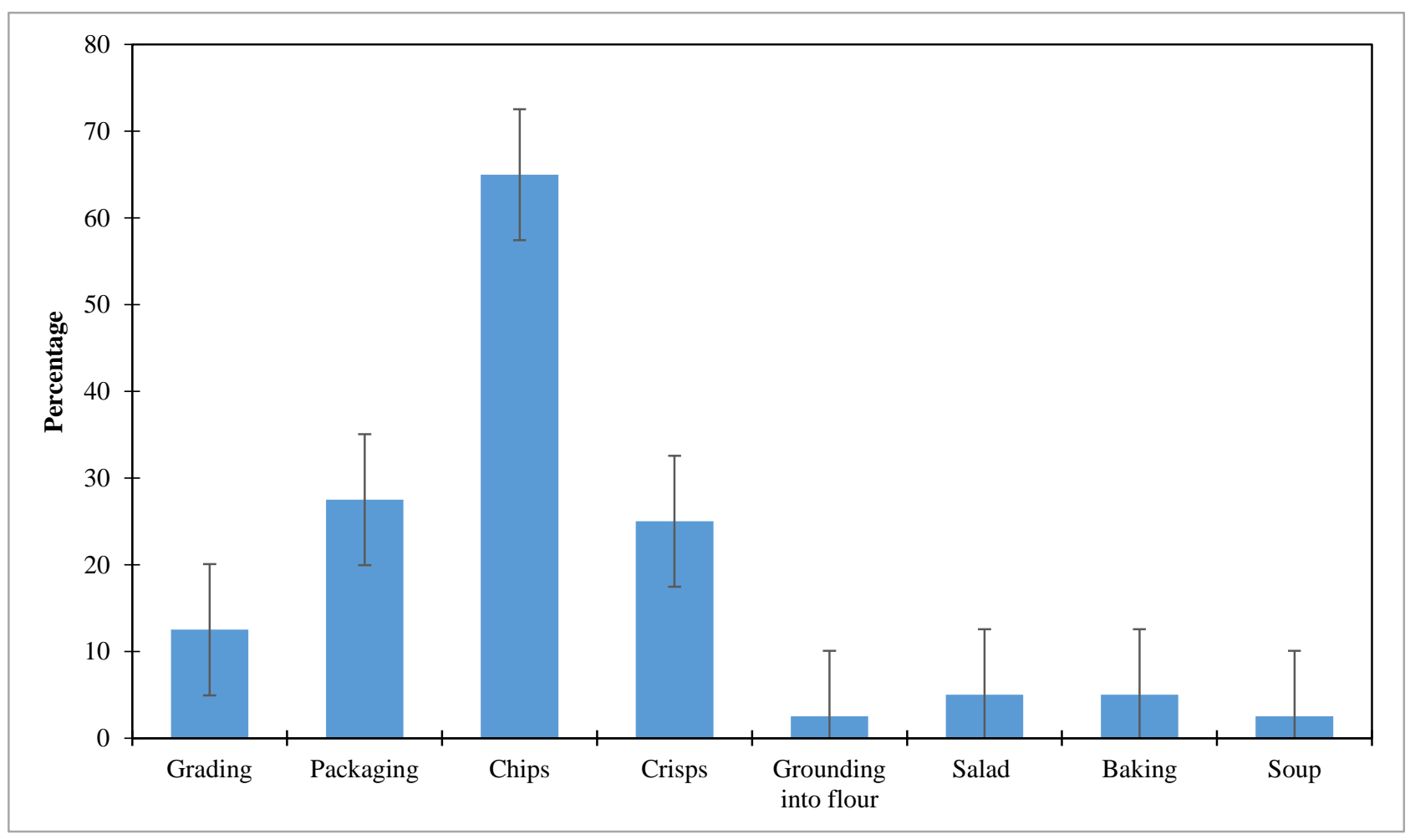

Figure 3. Value addition techniques involved

$X^{2}=103.3 ; d f=7 ; p<0.001$

(Bars means standard errors)

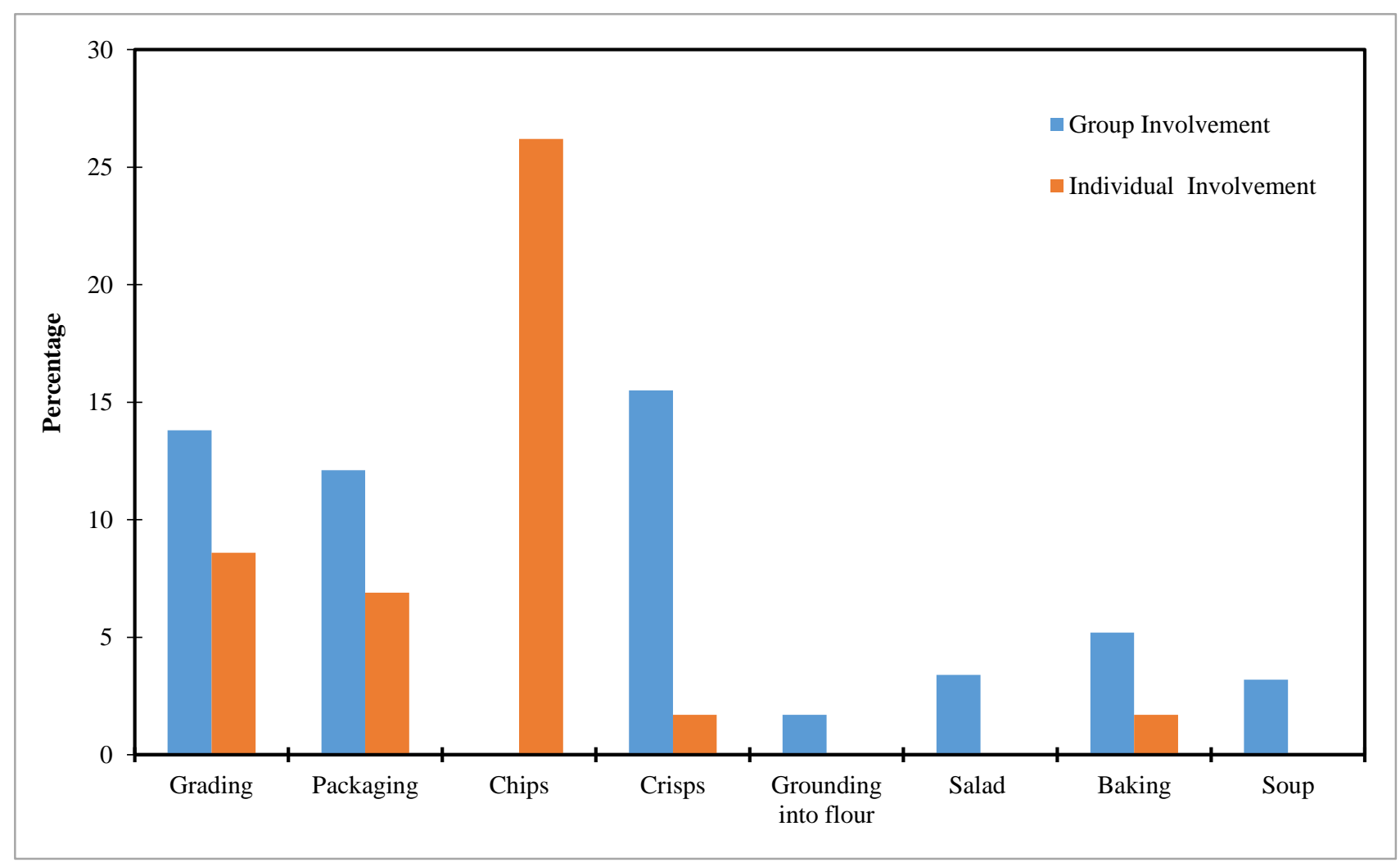

Figure 4. Value addition techniques in terms of group and individual involvement $X^{2}=42.657 ; d f=7 p<0.001$ 


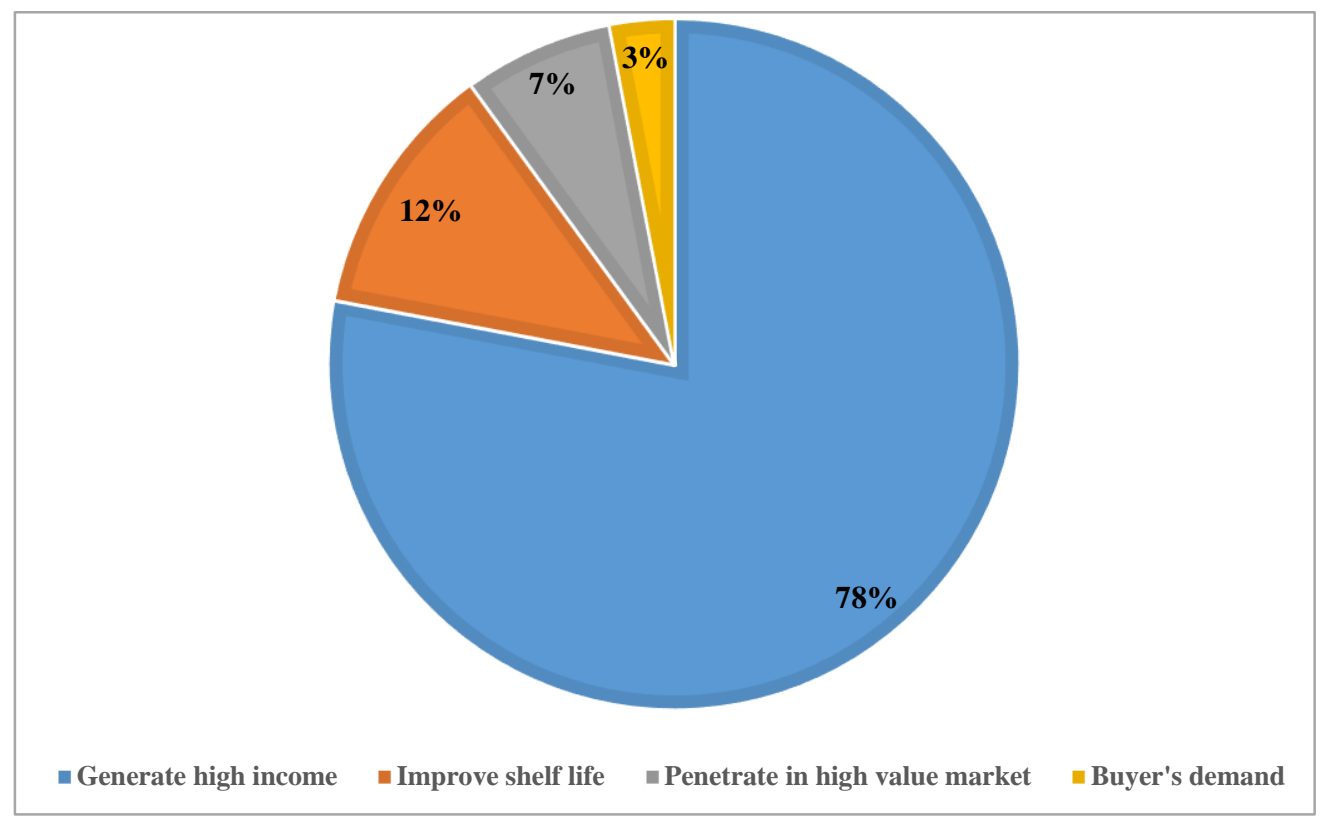

Figure 5. Reasons for engaging in value addition techniques $X^{2}=33.831 ; d f=3 p<0.001$

\section{3-3 Factors influencing value addition amongst Irish potato smallholder farmers}

Various factors that influenced Irish potato smallholder farmers in value addition are presented in Figure 6 . The results show that the factors significantly $\left(X^{2}=8.020 ; p=0.046\right)$ differed. The majority $(70 \%)$ of the smallholder farmers were influenced by knowledge of value addition, followed by ready markets for products $(57.5 \%)$, while a few were influenced by enough capital for value addition (45.5\%) and availability of value addition equipment (40.0\%).

Demographic characteristics like education level and group participation significantly $(P<0.05)$ influenced Irish potato value addition technique practices amongst the smallholder farmers (Table 3, Figure 7). On the other hand, age, gender, marital status and source of income had no implication on Irish potato value addition technique practice amongst the smallholder farmers (Table 3).

The results also revealed the following as the main challenges faced by smallholder farmers on Irish potato value addition: lack of access to credit loans, marketing of processed products, storage facilities and proper packaging and labelling (Table 4).

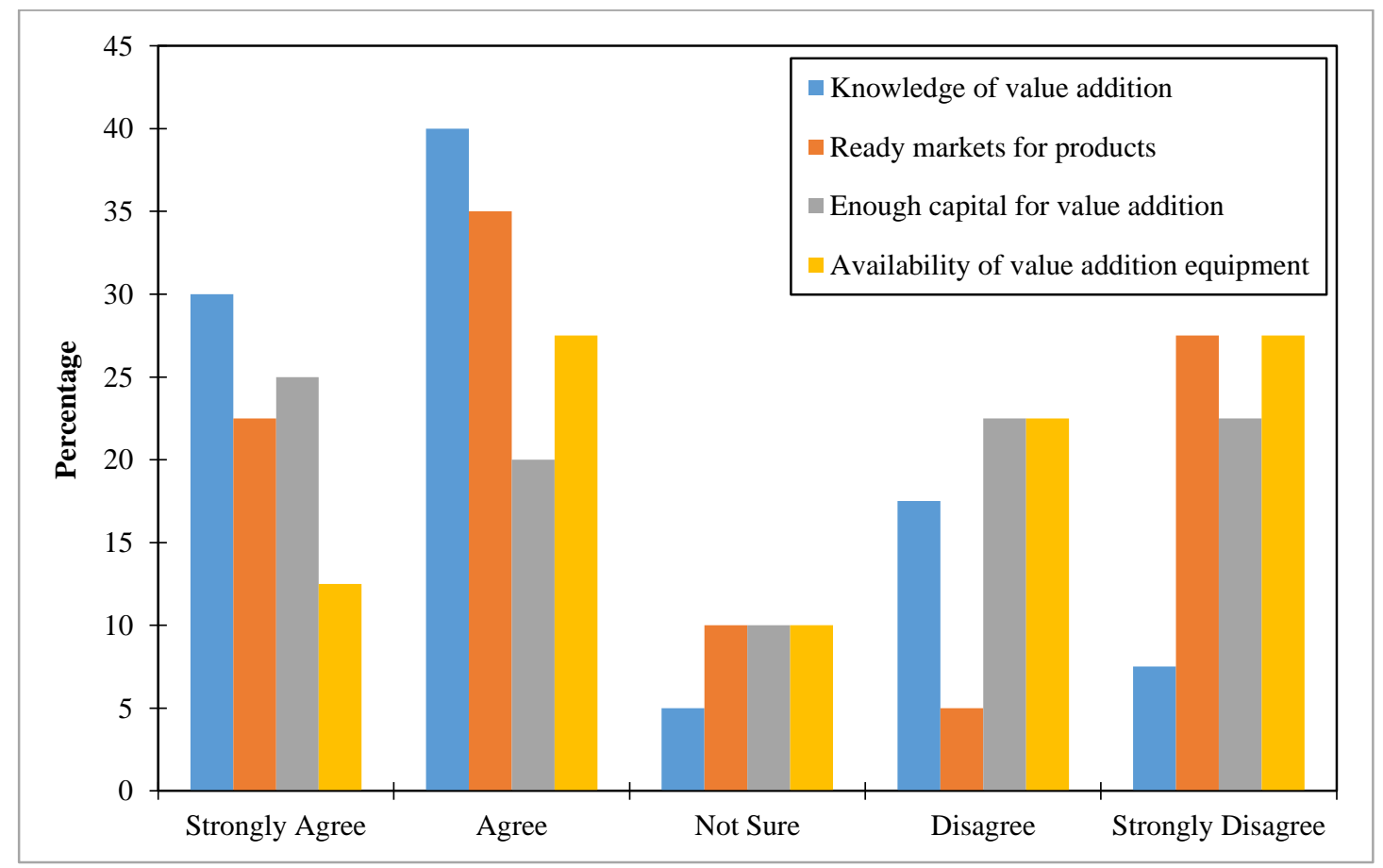

Figure 6. Factors that influence Irish potato value addition among smallholder farmers $X^{2}=8.020 ; d f=3 p=0.046$ 
Table 3. Influence of socio-demographic characteristics on Irish potato value addition

\begin{tabular}{cccc}
\hline Variable & Pearson Chi square & df & p-value \\
\hline Age group & 1.96 & 2 & 0.375 \\
Gender & 2.20 & 1 & 0.138 \\
Marital status & 3.27 & 2 & 0.352 \\
Education Level & 6.02 & 3 & 0.049 \\
Source of income & 4.03 & 3 & 0.259 \\
Group membership & 13.08 & 1 & $<0.001$ \\
\hline
\end{tabular}

Table 4. Challenges faced by smallholder farmers in value addition of Irish potato

\begin{tabular}{cccl}
\hline Challenges & Mean & SD & Scale \\
\hline Marketing of processed products & 3.78 & 1.65 & Agree \\
Proper packaging and labelling & 3.50 & 1.41 & Agree \\
Lack of access to credit loans & 3.98 & 1.47 & Agree \\
Storage facilities & 3.57 & 1.36 & Agree \\
\hline
\end{tabular}

Note: SD=Standard deviation; Scale interpretation; Strongly agree $=4.45-5.00$; Agree $=3.45-4.44$; Not Sure $=2.45-3.44$; Disagree $=1.45-2.44 ;$ Strongly disagree $=1.00-1.44$.
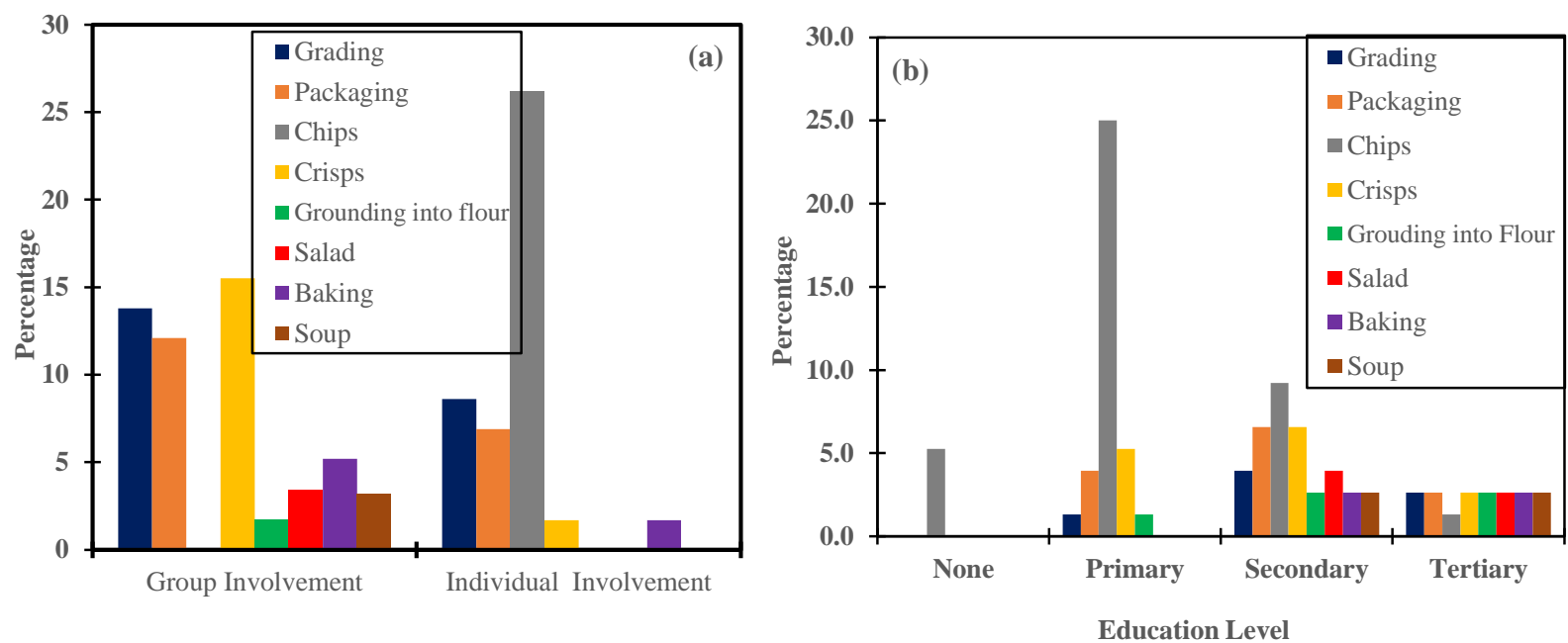

Figure 7. Influence of group participation (a) and education level (b) on Irish potato value addition practiced $X^{2}=4.997 ; d f=3 ; p=0.172$

\section{3-4- Strategies on How to Promote Effective Irish Potato Value Addition among Smallholder Farmers}

Respondents suggested differently on the strategies to promote effective Irish potato value addition among the smallholder farmers (Figure 8). The highest number of respondents $(61 \%)$ indicated that there is a need to encourage farmer group formation. About two tenths of the respondents $(21 \%)$ indicated that smallholder Irish potato farmers should have access to loans to buy value addition equipment. At least one tenth of the respondents (11\%) indicated that there is a need to link smallholder Irish potato farmers with supermarkets, and the remaining respondents (7\%) indicated that smallholder Irish potato farmers should be exposed to field days and workshops. 


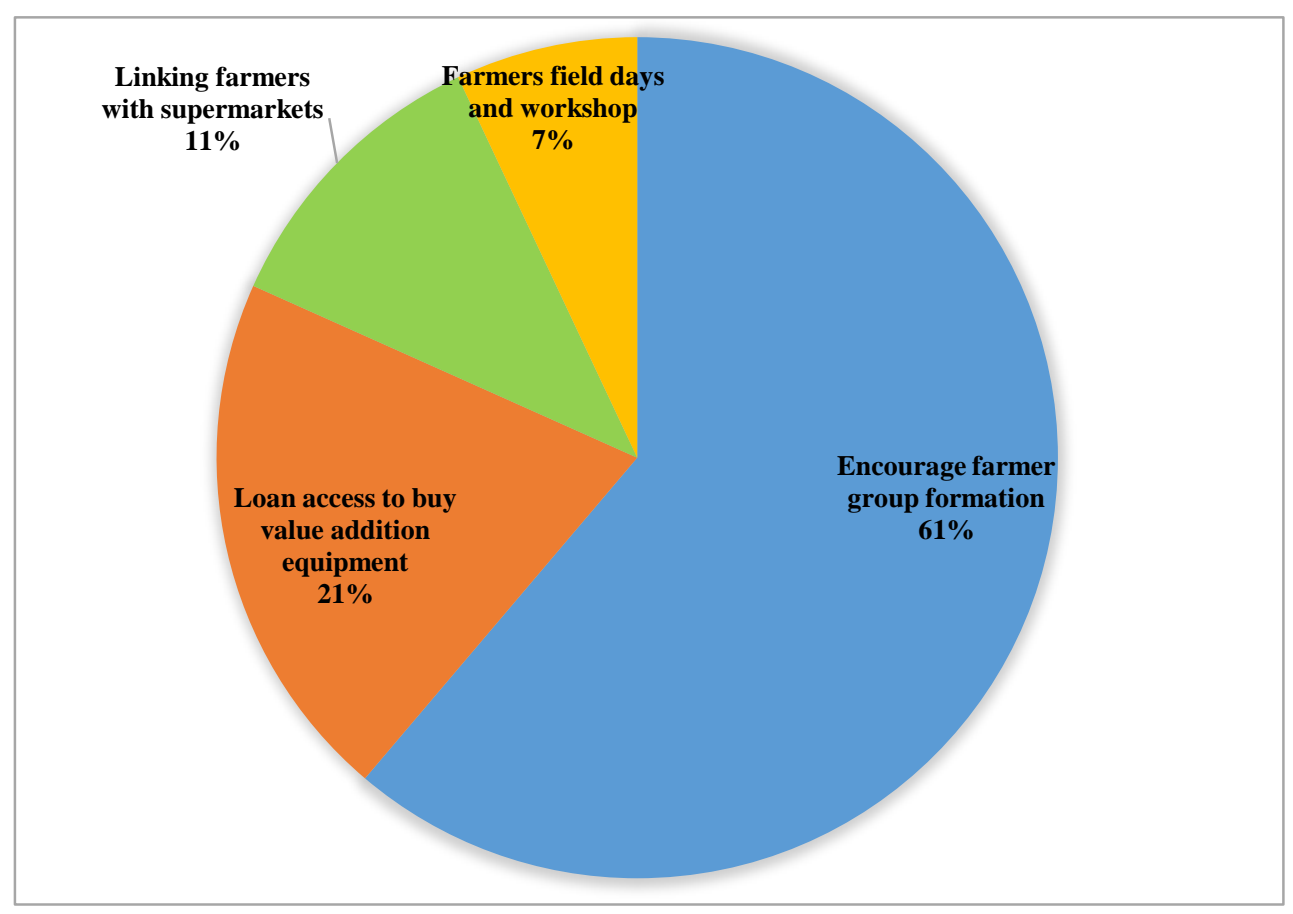

Figure 8. Suggested strategies to promote effective Irish potato value addition $X^{2}=70.547 ; d f=3 ; p<0.001$

\section{4- Discussion}

\section{4-1- Irish Potato Value Addition Techniques}

The result shows that Irish potato farmers in Njolomole Extension Planning Area engaged in different value addition techniques. These techniques included: grading, packaging, chips, crisps, grounding into flour, salad, baking and soup. It was observed that the smallholder farmers are involved in different Irish potato value addition techniques with the purpose of generating high income hence improve their living standard. This is in agreement to Nungo et al. [10] who stated that value addition techniques are intended to improve shelf life, increase incomes and improve food security of the rural poor farmers. Similarly, Gumataw et al. [17] indicated that processing, perishable farm produce reduces bulkiness, diversify consumption and enhance acceptability and marketability, increases shelf life hence contribute significantly to household food security and income generation since wastage is minimized.

Although, Irish potato smallholder farmers in Njolomole EPA are involved in different value addition techniques, but the involvement significantly differed among the value addition techniques. Majority of the farmers $(65 \%)$ are engaged in chips, while few $(2.5 \%$ to $27.5 \%)$ are engaged in other value addition techniques. A greater percentage of smallholder Irish potato farmers engaging in chips value addition technique may be explained by the fact that the technique is simple, requires little capital and also that the farmers have knowledge of preparing potato chips since it is commonly found. In addition, potato chips are marketable since most workers in the study area eat potato chips as their lunch. On the other hand, few farmers are engaged in the other value addition techniques (packaging, crisps, baking, soup, salad, and grounding into flour) because they are considered as advanced techniques of value addition which require more inputs [18]. Interestingly, on grading a lot of farmers believe in mixing the potato. Thus, farmers put small potatoes in the bottom of the bucket and large potatoes on top of the bucket in order to attract customers. The present findings are in line to those in literature. Teklemariam [19] reported that smallholder Irish potato farmers in Nigeria are engaged in different value addition techniques which include crisps, chips, baking and salad. However, most of the farmers $(59 \%)$ were involved in potato chips value addition technique, because of the simplicity of the technique. The results reported by Kyalo [20] on Irish potato value addition techniques practiced by smallholder farmers in Kenya also support the findings of the present study. Kyalo [20] reported that smallholder Irish potato farmers in Kenya are engaged in various value addition techniques (crisps, chips, salad, baking, flour, grading and packaging). He further reported that Irish potato acts as a staple food crop as well as cash crop for many rural and semi urban dwellers in Kenya playing an important role in improving national food security and income generation for those involved in its value chain development.

\section{4-2- Factors Influencing Value Addition amongst Irish Potato Smallholder Farmers}

Various factors influenced Irish potato smallholder farmers in value addition. However, majority (70\%) of the smallholder farmers were influenced by knowledge of value addition, followed by ready markets for products $(57.5 \%)$, while a few were influenced by enough capital for value addition $(45.5 \%)$ and availability of value addition equipment 
(40.0\%). This indicates that knowledge is very important in adoption of value addition techniques [18]. In addition, farming is a business so a good entrepreneur needs to know market before production in order to enhance profit. Furthermore, every business need enough capital and availability of the equipment to be successful, capital determine what kind of business to be conducted [19].

The study further revealed that demographic characteristics like education level and group participation significantly $(P<0.05)$ influenced Irish potato value addition technique practices amongst the smallholder farmers. Smallholder Irish potato farmers with secondary and tertiary education level were engaged in various value addition techniques (80-100\%) while those with primary and no formal education were engaged in few value addition techniques (20-40\%). This indicates that farmers with higher education have better access to information and knowledge that are beneficial to farming operation [21]. In addition, Otieno [22] reported that highly educated farmers also tend to adopt technology with greater intensity. This indicate a need for people to be really educated because technology advancement will never cease [18]. In addition, few respondents had secondary (25\%) and tertiary education (5\%). This shows that most of them cannot find a job as a results they go into Irish potato farming in order to earn their living. Majority of smallholder farmers who joined groups are involved in diverse value addition techniques (88\%) compared to few (12\%) who did not join any group. According to Orinda [23] group membership positively contributes to the extent of value addition and this can be explained by the fact that individuals in groups are easily influenced by their associates than those in isolation. Most farmers who are members in different farmer groups participated in value addition. This can be attributed to the fact that farmers in groups get to exchange ideas and influence each other leading to adoption of value addition techniques. Group membership ensures collective production, marketing, training ensuring pooling of resources together and reduction of information asymmetry thus reducing transaction costs and ensuring economies of scale.

On the other hand, age, gender, marital status and source of income had no implication on Irish potato value addition technique practice amongst the smallholder farmers. However, majority $(67.5 \%)$ of the respondents were male compared to female $(32.5 \%)$, this shows that most of the farmers who grow Irish potato and adding value are males and this is so because Irish potato is taken as a house hold source of finance. Therefore, more men work hard in Irish potato production in older to support their families. In addition, most (57.5\%) of the respondents fell within the age bracket of $20-29$ years. This indicates that most of value addition techniques of Irish potato are conducted by young people this is because young people are flexible easy to adopt new technology and also they easily excess media where they get a lot of information. In contrast, Orinda [23] reported elder ages engagement in value addition than young ones. He argued that old age comes with experience while at the same time, younger people might view engagement in value addition as a menial job thus look for white collar jobs.

\section{4-3- Strategies on How to Promote Effective Irish Potato Value Addition among Smallholder Farmers}

The study identified the following as strategies to promote effective Irish potato value addition among smallholder farmers: encourage farmer group formation, access to loans to buy value addition equipment, link smallholder Irish potato farmers with supermarkets, and exposing farmers to field days and workshops.

According to Orinda [23], farmer group formation this helps farmers to share knowledge on techniques for value addition. It also reduces transaction cost. Lack of information leads to high transaction cost and group formation leads to economic of scale, since in a group they buy inputs at a wholesale and this reduces high bargaining hence more profit for smallholder farmers. In addition, Yohannes [24] argued that the most essential issue in adopting a new technique is group formation. Such group formation is attributed to a spirit of teamwork and cooperation where there is communication. Furthermore, membership to a group may enable farmers to learn about a technique via other farmers and from other development agencies. Information flow between members of farmer groups is usually very rapid and essential. Farmer groups give their members a wider opportunity for educating each other. Higher interactions among members of a group increase chances to widen understanding of new technique and their advantages.

The second strategy identified is that smallholder Irish potato farmers should have access to loans to buy value addition equipment. This strategy will help a lot of farmers to engage in value addition hence increase their revenue since most farmers have challenges on availability of equipment. So financial institutions like; banks, FINCA should be encouraged to give out loans to farmers because they do not like giving loans to farmers. Since agriculture is considered as a risk by nature and also most smallholder farmers do not have collate that financial institutions demand. Access to credit enables farmers to acquire value addition equipment [23]. According to Svubure et al. [25] farmers with better access to credit are significantly more likely to be adopters of the technology and that credit schemes tend to focus on the distribution of very few inputs but restricted to only few group of farmers.

Linking smallholder Irish potato farmers with supermarkets is one of the essential strategy to promote effective Irish potato value addition among smallholder farmers. This strategy helps to improve quality of products supplied [23]. According to Otieno [22], finding ways to link smallholder farmers to markets is generally considered a critical part of any long-term development strategy to reduce poverty and hunger. 
Exposing to field days and workshops is also essential in promoting effective value addition among smallholder Irish potato [19]. Through field days and workshops farmers acquire skills and techniques they need to engage in value addition. Access to field days and workshops has been widely reported to positively influence adoption and continued use of agricultural technologies [26]. Similarly, the frequency of field days and workshops by farmers was found to be significantly influencing the decision to use new agricultural technology. This is because field days and workshops provide information, knowledge and skills that enable farmers to be aware and use the technology. Field days and workshops play a central role of providing support for institutional mechanisms designed to support the dissemination and diffusion of knowledge among farmers and demonstration of gains from new technologies [27-30].

\section{5- Conclusion}

The study revealed that farmers in Njolomole EPA are engaged in different Irish potato value addition techniques. These include: grading, packaging, crisps, chips, grounding into flour, baking, salad, and soup. However, most farmers are engaged in potato chips value addition because it is simple and marketable. It was noted that various factors influenced Irish potato value addition among smallholder farmers. These include: knowledge of value addition, ready markets for products, enough capital for value addition, and availability of value addition equipment. The study further revealed that demographic characteristics like education level and group participation significantly influenced Irish potato value addition technique practices. Farmers with secondary education level or above and those in Irish potato group production are involved in diverse value addition techniques. Encouraging farmer group formation, access to loans to buy value addition equipment, linking farmers with supermarkets, and farmer's exposure to field days and workshops are the strategies identified to promote effective Irish potato value addition among smallholder farmers.

\section{6- Acknowledgements}

The authors are grateful to the participating farmers and other groups that provided information during the study. The authors acknowledge Academic staff of the Agricultural Department, Malawi Adventist University, Lake View Campus for critiquing earlier draft of this work. The editorial team and the anonymous reviewers also deserve many thanks for helping to improve this publication through their constructive pieces of advice.

\section{7- Conflict of Interest}

The authors declare no conflict of interest.

\section{8- References}

[1] International Potato Center (CIP). "Potatoes for the Developing World: A collaborative Experience.” Lima Peru (2004): 13-20.

[2] Food Early Warning System Network (FEWSNET). Crop estimate statistics for 2007-2008. Ministry of Agriculture, Lilongwe, Malawi and Agriculture Organization of the United Nations. International Year of the Potato, (2008).

[3] Assa M. Maganga. "Technical Efficiency and Its Determinants in Irish Potato Production: Evidence from Dedza District, Central Malawi.” African Journal of Agricultural Research 7, no. 12 (March 26, 2012): 192-197. doi:10.5897/ajar11.1463.

[4] Hogan, S. "Irish potatoes leading a revolution in Malawi." Worldandmedia.com, (2015).

[5] Reece, S. "Potato Nutrition Handbook." Denver, Colorado, USA, (2015).

[6] Ayodele, Matthew Ojo. "Economic Analysis of Irish Potato Production in Plateau State." PhD diss., 2005.

[7] Ugonna, C.U., M.O. Jolaoso and A.P. Onwualu, “A technical appraisal of potato value chain in Nigeria.” International Research Journal of Agriculture and Soil Science 3, no. 8 (September 3, 2013): 291 - 301. doi:10.14303/irjas.2013.084.

[8] World Bank Report. "International year of the potato, 2008." Hidden Treasure, (2009).

[9] Agajie, T., G. Woldegiorgis, W. Kaguongo, B. Lemaga and D. Nigussie. "Adoption and impact of potato production technologies in Oromia and Amhara Regions. Paper presented at the National Workshop on seed potato tuber production and dissemination, 12 -14 March 2012, Bahir Dar, Ethiopia, (2013).

[10] Nungo, R.A., P.J. Ndolo, R. Kapinga and S. Agili. "Development and promotion of sweet potato products in Western Kenya." Proceedings of the 13th ISTRC symposium (2007): 790 - 794.

[11] Bonabana-Wabbi, J., S. Ayo, B. Mugonola, D. B. Taylor, J. Kirinya, and M. Tenywa. "The performance of potato markets in South Western Uganda." Journal of Development and Agricultural Economics 5, no. 6 (2013): 225-235.

[12] Fuglie, Keith O. "Priorities for Sweetpotato Research in Developing Countries: Results of a Survey." HortScience 42, no. 5 (August 2007): 1200-1206. doi:10.21273/hortsci.42.5.1200. 
[13] Rural Livelihood Economic Enhancement Programme (RLEEP). “Programme Evaluation Report November 2014.” Ministry of Local Government and Rural Development, Lilongwe, Malawi, (2014).

[14] Churchill G.A. and D. Lacobucci. "Marketing Research Methodological Foundations.” 12nd Edition. New York: Dryden Press (2018).

[15] Anderson, David R., Dennis J. Sweeney, Thomas A. Williams, Jeffrey D. Camm, and James J. Cochran. "Statistics for business \& economics.” Nelson Education, 2016.

[16] McClave, J.T., P.G. Benson and T. Sincich. “Statistics for Business and Economics, 13th Edition.” (2017).

[17] Abebe, Gumataw K., Jos Bijman, Stefano Pascucci, and Onno Omta. “Adoption of Improved Potato Varieties in Ethiopia: The Role of Agricultural Knowledge and Innovation System and Smallholder Farmers' Quality Assessment.” Agricultural Systems 122 (November 2013): 22-32. doi:10.1016/j.agsy.2013.07.008.

[18] Tewodros, Ayalew, C. Struik Paul, and Hirpa Adane. "Characterization of Seed Potato (Solanum Tuberosum L.) Storage, PrePlanting Treatment and Marketing Systems in Ethiopia: The Case of West-Arsi Zone.” African Journal of Agricultural Research 9, no. 15 (April 10, 2014): 1218-1226. doi:10.5897/ajar2013.8572.

[19] Teklemariam, Tebabal Misikir. "The Impact of International Potato Center's Nutrition Project on Smallholder farmers' Income and Adoption of Improved Potato Varieties: Tigray region, Northern Ethiopia." PhD diss., Mekelle University, 2014.

[20] Kyalo, J. "Potato Production in Kenya." (2014). https://mfarm.co.ke

[21] Mishra, A.K. "Net effects of education on technology adoption by U.S. farmers." Selected Paper prepared for presentation at the Southern Agricultural Economics Association Annual Meeting, Orlando, FL, February 6 - 9, 2010. (2010).

[22] Otieno, D. "Smart Farm: Potato value addition in Limuru.” (May, 2016).

[23] Orinda, Mary Akinyi. "Analysis of factors influencing sweet potato value addition amongst smallholder farmers in Rachuonyo South District, Kenya." PhD diss., Egerton University, 2013.

[24] Yohannes, B. "Review of Value Chain Analysis of Potato in Ethiopia." International Journal of Advances in Scientific Research and Engineering (2018): 8 - 17. doi:10.7324/ijasre.2018.32660.

[25] Svubure, O., P.C. Struik, A.J. Haverkort, and J.M. Steyn. "Yield Gap Analysis and Resource Footprints of Irish Potato Production Systems in Zimbabwe.” Field Crops Research 178 (July 2015): 77-90. doi:10.1016/j.fcr.2015.04.002.

[26] Svubure, O, PC Struik, AJ Haverkort, and JM Steyn. "Analysis of the Potato (Solanum Tuberosum L.) Value Chain in Zimbabwe.” Outlook on Agriculture 46, no. 1 (March 2017): 49-56. doi:10.1177/0030727017690655.

[27] Mbowa, S. and F. Mwasigye. "Investment Opportunities and Challenges in the Irish Potato Value Chain in Uganda." Research Report No. 14. (2016).

[28] Sebatta, Christopher, Johnny Mugisha, Enid Katungi, Apolo Kasharu, and Harriet Kyomugisha. "Adding Value at the Farm: The Case of Smallholder Potato Farmers in the Highlands of Uganda." Asian Journal of Agricultural Extension, Economics \& Sociology 4, no. 3 (January 10, 2015): 210-223. doi:10.9734/ajaees/2015/13844.

[29] Agwu, N.M., C.I. Anyanwu, and U.H. Kalu, "Factors Influencing Cassava Value Addition by Rural Agribusiness Entrepreneurs in Abia State, Nigeria." Scientific Papers Series Management, Economic Engineering in Agriculture and Rural Development 15, no. 3 (2015): $19-24$.

[30] Omoare, A. M., E. O. Fakoya, O. E. Fapojuwo, and W. O. Oyediran. "Awareness of Value Addition of Sweet Potato (Ipomoea batatas (L.) Lam) In Osun State, Nigeria." World Academy of Science, Engineering and Technology, International Journal of Biological, Biomolecular, Agricultural, Food and Biotechnological Engineering 8, no. 1: 20-24. 